\title{
CONDENSATION, TRAUMA AND PERCEPTIVE DENSITY OF LANGUAGE - FREUD WITH JORGE LUIS BORGES
}

Tainá Pinto and Tania Rivera

Tainá Pinto

Universidade de Brasília (UnB), Programa de Pós-Graduação em Psicologia Clínica e Cultura, Brasília/ DF, Brasil.

Tania Rivera Universidade Federal Fluminense (UFF), Programa de Pós-Graduação em Estudos Contemporâneos das Artes, Niterói/ RJ, Brasil.

\begin{abstract}
This essay examines the question of perceptual vividness, which will lead to an exploration of condensation in its articulation with trauma. A hypothesis is then formulated around the existence of two different types of reproduction of the traces inscribed in the psychic apparatus: one to do with memory, the other with re-living. Jorge Luis Borges' story 'The Aleph' helps us to thinkabout those traces as the letter — and about its relationship with perception as traumatic excess.
\end{abstract}

Keywords: condensation, trace, trauma, perception.

RESUMO: A Condensação, o Trauma e a Densidade Perceptiva da Linguagem - Freud com Jorge Luís Borges. O exame da questão da vivacidade perceptiva no sonho leva, neste ensaio, à condensação em sua articulação com o trauma. Formula-se então a hipótese da existência de dois tipos diferentes de reprodução dos traços inscritos no aparelho psíquico: um de memória e outro de revivescência. O conto "O Aleph", de Jorge Luís Borges, ajuda a pensar o traço como letra e sua relação com a percepção como um excesso traumático.

Palavras-chave: condensação, traço, trauma, percepção.

DOI - http://dx.doi.org/10.1590/S1516-14982016002011 
$\mathrm{I}_{\mathrm{ag}}^{\mathrm{n}}$ n his 1949 story "The Aleph", Borges presents us with an unconceivable image. In it, his character encounters with this minuscule iridescent sphere that contains the whole universe: the aleph, the place where all the places on earth lie, distinct, and seen from every angle. A vertiginous spectacle that encompasses all impossibilities, as Blanchot (2005) suggests. The whole space reveals itself suddenly, at once, in a single point of space. Each thing transforms into an infinity of things when seen from all the angles, and all that without any transparency or overlapping.

For the aleph everything converges, as if it were exhibiting the maximum condensation power possible. It is the densest and most concentrated point one could conceive since it contains the whole universe in itself. And that numeric power Borges seems to lend from the mystic theory of the kabbalah, as he reveals at the end of the story, in a remark about the name aleph: "As is well known, the Aleph is the first letter of the Hebrew alphabet. It is sure for the strange sphere in my story may not be accidental. For the Kabbalah, the letter stands for the En Soph, the pure and boundless godhead". (BORGES, 1949/2008, p. 152). The En Soph, according to Sosnowski (1991), is the infinite dimension of God; according to Scholem (2006), it is infinity, with no beginning, the uncreated, root of all roots.

For the Kabbalah, the aleph is the letter. Scholem (1995) states that no matter how heterogeneous is the field of mystic Judaism is, the cabbalists, who differ in almost everything, unanimously agree to consider language as something precious. Hebrew, the sacred tongue, is not a mere means to express our thoughts; Hebrew is language at its purest state, and it was the divine instrument of creation. God would have drafted, sculpted, weighted, combined and modified the twenty-two letters of the alphabet and created the world through them.

Among all the letters, the aleph is a special one. According to Sosnowski (1991), it's the letter favored by God. The author tells that in the introduction to the Zohar, the sacred book, there's a long argument about the struggle between the letters to obtain the honor of being the first one. God would have chosen the aleph as some form of consolation, since between all the letters it was the only one lacking a plural. The aleph, as God, as the Torah, is one, and that's why it was chosen to head the alphabet.

It is with the aleph — that primordial letter — that the Ten Commandments begin. Scholem (2006) presents some of the existing versions for the transmission of the divine laws to mankind. One of them sustains God's voice was too oppressive for human ears, and the only thing that the people of Israel got to hear from the mouth of God would be the aleph in the word anokhi, 'I'. Only Moses was allegedly capable of tolerating the divine voice and would, then, have acted as mediator and repeated the Ten Commandments in a human voice. Another version states that in a deliberate action God wanted his revelation to consist only 
in the aleph. A mystic revelation that in the author's perspective is full of infinite meaning, at the same time as it doesn't have any specific meaning.

The aleph is then the original letter. Cabbalists consider it the spiritual root of all other letters, encompassing the whole alphabet in its essence and therefore all the other elements of human interlocution. Interestingly, that letter, so powerful, cannot be articulated. As Scholem (2006) explains, in Hebrew, the consonant aleph represents nothing but the position adopted by the larynx when a word begins with a vowel. In this way, the aleph describes the source of all and any articulated sound, but hearing the aleph is equivalent to hearing practically nothing. It's merely a sort of preparation for the audible language. An almost unpronounceable letter that contains the origin of all and any human sentence, all possibilities of expression and, in the last stance, contains the universe itself — justas Borges suggests in the spectacular and impossible image his taledraws.

\section{THE TRIMETHYLAMINE}

Another letter as dense and powerful as the aleph seems to be found in the great inaugural dream of psychoanalysis, the dream of the injection of Irma (FREUD, $1900 / 2012$, p.128). In the end of that dream, suddenly, the formula of the trimethylamine emerges before Freud, written in bold. Enigmatic, it is surrounded with airs of mystic revelation, as the aleph. Lacan, in his reinterpretation of the dream, takes the formula as a word, as a word-prophecy, that does not provide any answer whatsoever. For him, it is a final word that 'doesn't mean anything' (LACAN, 1954-55/1985, p. 216).

In Freud's interpretation it's evident that the formula, enigmatic and meaningless, is some kind of number. It is the result of the densification of numerous dream-thoughts. Thetrimethylamineemerges in thedream aftera certain explicit doubt in the metonymic displacement. When Irma was feeling ill, Otto should have injected her with: Propyl? Propylene? Propionic acid? Trimethylamine! And then, in the dream, the formula appears in bold!

The trimethylamine, he tells us in his detailed associations, is 'an allusion to the preponderant factor of sexuality' (FREUD, 1900/2012, p.138). A crucial factor in the origin of nervous diseases, it is connected to the widowhood of his patient, alluding to the absence of sexual activity that, according to the convictions of the time, could be one of the reasons that prevented her from getting better. The trimethylamine also remits Freud to Fliess, a good friend with whom he starts having conflicts as he was writing this book. It was Fliess who wrote that substance down as one of the components of sexual chemistry (trimethylamine is a product of the decomposition of sperm, as Lacan indicates, 1954-55/1985, p.201). In his research, he established relation setween the nasal 
cavities and the female sexual organs. On Freud's request, Fliess himself would have examined Irma, to check if her stomach pain had nasal origin.

Besides the connection to sexuality, there's also a connection between the trimethylamine and the cocaine that in this text is forgotten (or underlined), noted by Freud himself in a previous text. In 'Über Coca', he says: 'besides cocaine, the following substances were found in coca leaves: coca tannic acid, a special kind of wax and a volatile hygrine base, whose scent reminds us of trimethylamine' (FREUD, 1884/1989, p.70). And cocaine, in the associations of the dreamer, has a clear connection with death. The drug doesn't appear in the evident content of the dream, but it is a recurring element in latent thoughts connected to the death of his friend Fleischl, whom Freud considered accelerated by the use of cocaine he himself prescribed to help him with his morphine dependency.

At the same time in which the trimethylamine 'doesn't mean anything', as Lacan reads, it also points at a large number of dream-thoughts connected to death and sexuality. Its chemical formula closes Freud's dream as a very clear figuration of the role of language in the functioning of a dream: encoding of our own wishes, of ourselves as subjects. Amidst the interpretative profusion inaugurated by psychoanalysis, the letter is the navel that matches the terrible image of Irma's open mouth facing the dreamer, she being the gutter through which all meaning slips for the visual presentation, in language, of what makes any meaning impossible.

\section{THE NAVEL AND CONDENSATION}

The navel of the dream is the great discovery made by Freud in The Interpretation of Dreams or, at least, the most radical discovery in that work. He subverts the very notion of interpretation and questions the limits of the interpretable. A discovery as crucial as finding out that dreams have a meaning, that they fulfill wishes and are structured according to their own laws (condensation, displacement and consideration for representability) and a discovery that questions up to what point we can attribute meaning. The navel of the dream is the second time, the second turn of the Freudian discovery, where all the virulence of this work lies.

This very fundamental notion is connected with condensation, which forces us to examine the concept. In the pair condensation/displacement, the first element is preponderant in the writing of 'The Interpretation of Dreams'. Even if Freud doesn't tackle that primacy, it's impossible to avoid perceiving that he quickly touches displacement (barely five pages), and he extends considerably on condensation. Besides, many times the displacement is approached through the book as a work at the service of condensation. This is what we can observe, for instance, in connection with what Freud calls 'nodal point' of the dream. 
A nodal point is the core of the logics of the construction of the dream. Succinctly, we can say that it is the element of the manifest content where multiple dream-thoughts converge. It is the nucleus of the chain of thoughts, and with each of these thoughts it has at least one link, not univocal but multidirectional. It is possible to go from one nodal point to several dream-thoughts, as it is possible to go from an oneiric thought to several nodal points. That's because the many chains of thought establish connections between each other, forming a complex network.

In this way, a nodal point is the result of the work of condensations that gather several thoughts in only one element. These nuclear or multinuclear chains are synchronic and the dream is the final calculation of the combination of all of them. Hence, the dream can be conceived as the result of a second condensation that would combine the synchronic nucleuses of thought. Such final condensation seems to enhance the first one, making the links between thoughts even more complex.

As they concentrate psychic intensities from the most diverse thoughts, the nodal points are very dense and meaningful. For a nodal point to be able to concentrate psychic intensity, it is necessary that the intensities be displaced from the thoughts to this central element. There, in a certain way, we find displacement at the service of condensation, insofar as the convergence and concentration in a single point are only possible thanks to the discharge of psychic intensities.

Trimethylamine is, without a doubt, a nodal point of the Freudian dream. It is an element of the manifest content where, as we have mentioned, diverse dream-thoughts related to death and sexuality converge. The crucial matter that Freud raises early in the beginning of the chapter about condensation is that the volume or limit of condensation is always undeterminable. That is one of the reasons why a dream can never be interpreted totally, that's one of the limits of the interpretation. A curious limit, since it's not connected to a restriction but rather to the unlimited. An interpretation is always partial and therefore infinite, it is always to be made, since a new associative path can always come up.

We consider that precisely the core of the navel of the dream. Freud states that even in the most acutely interpreted dreams we can always leave 'a point in the dark', since it is observed that during the interpretation 'begins a skein of dream-thoughts that won't let it untie'. That entangled point is for him the navel of the dream, 'the point in which it (the dream) settles in the unknown' (FREUD, 1900/2012, p. 552). The navel hence imposes a rest (the dark point), and limits the interpretation not by lack or absence of interpretations, but by excess of them: a disruptive excess that paralyzes and hinders the explanation of the associative network. 
As the interpretative process is unfinished by nature, it is inherent to the way in which the dream is structured around synchronic nucleuses of thoughts - the nodal points - each of these nucleuses can be thought as a potential navel of the dream. The very notion of navel leads us to think that no chain of dream-thoughts could be completely retaken in the dreamer's associations, that is, no nodal point can be completely elucidated in its associations. There is a rest, something that is always lost. The navel might be the nodal point that is so condensed that became a skein. And it is strange that Freud states: 'From a denser point of that entanglement, the oneiric wish rises as a mushroom from its mycelium' (FREUD, 1900/2012, p. 552). The navel contains the origin and the end of the dream, it's from it that the dream emerges and it's in it that the interpretation is interrupted.

\section{PERCEPTIVE VIVIDNESS AND CONDENSATION}

Something worth noticing is the way in which the trimethylamine formula appears in the dream: perceptively, very vivid. Freud sees it in bold letters in front of himself. The perceptive vividness and the variation of its intensities is part of the Freudian concerns. He establishes a very clear connection with condensation proposing that the most vivid elements are also the clearest ones. Most of the thought chains start from these dense elements: 'The elements of the dream that show maximum intensity are those in whose formation the most abundant condensation work was used' (FREUD, 1900/2012, p.353).

The same excess vividness is also a paramount distinctive quality of the socalled screen memories. As known, these memories do not stand out due to their content, which normally refers to trivial situations, but due to their form. These are marking memories for the richness of the detail as well as for the sensorial excess that they carry and that the subject deems to re-experience each time he remembers. As in the dreams, in these memories there are some elements that stand out for their high vividness. In the same way as in that scene described by Freud in which the dandelion flowers stand out for their 'disproportionately relevant' yellow, as the bread for its delicious flavor, exaggerated 'in an almost hallucinatory way' (FREUD, 1899/1996, p. 294).

According to Rivera (2008) screen memories are a kind of infantile short film, sharing with cinema a fundamental technique: editing. These mnemonic constructions would teach us that a scene hides another one, preventing us from seeing too much. Something essential that cannot be revealed in that way is substituted by something banal. Excessively vivid points would be the gaps in the scene, the indicators of the presence of the editing: being so intense, they are out of tune with the rest and seem more real than reality itself. Rivera 
defends a relation between the excess intensity and the trauma: in an editing trick, the scene that reveals itself hides the traumatic scene, whose presence is told through the vivid elements.

The way in which these points of high perceptive vividness are formed is possibly the same, both in dreams and screen memories. In both situations there are extremely vivid elements that reveal themselves as highly condensed. And the excess is related to the trauma, where everything points at, seeking to cover it. What we pretend here is to detail this relation between vividness and trauma through Freud's work.

\section{THE PSYCHIC APPARATUS AND REGRESSION}

The excess in perceptive vividness reveals itself as a formal trace of the dream that notifies about its construction process since it indicates the points where a large number of oneiric thought chains converge. In order to understand how the condensation work is more abundant in some points of the dream than in others, it's necessary to go through the paths that Freud marked when he conceived his model of psychic apparatus and the concept of regression.

The psychic apparatus conceived by Freud in The interpretation of Dreams is one whose drawing resembles a comb. This is an optical apparatus, as indicated by the comparisons he established with instruments that form virtual images, like microscopes and telescopes. This apparatus is essentially reflexive, that is to say that it barely responds to stimuli. Furthermore, it is composed by systems and it has spatiality. The spatial orientation of its systems is constant: a stimulus goes through a fixed sequence; hence it always goes from the perceptive end (the one receiving the stimulus) to the motor end (the one that responds to stimuli through motility). Between one end and the other we find the mnemonic systems, responsible for the preservation of memory traces of the stimuli received.

Thinking about the dreams of high perceptive vividness, Freud assumes the possibility that the arousal can take the opposite direction, a regressive one, within the apparatus. Instead of spreading in the direction of the motor end, in a progressive direction, it takes the inverse path towards the sensitive end, thus reaching the perceptive system in which it was originated. The state of dreaming favors the regressive path, since it restricts motility almost completely. However, condensation also makes a fundamental contribution to regression:

When we spoke of the condensation-work of the dream we could not avoid the assumption that by the dream-work the intensities adhering to the ideas are completely transferred from one to another. It is probably this modification of the usual psychic process, which makes possible the cathexis of the system of $\mathrm{P}$ (perceptive 
system) to its full sensory vividness in the reverse direction to thinking. (FREUD, 1900/2012, p. 571)

It is then condensation the one that enables the reversion of the perceptive system until a full sensorial vividness, whose doors are open during the dream. Thoughts need to be concentrated to manage to go through the reverse path within the apparatus. Remarkably, Freud realizes there is a selection criteria, it's not any thought that can regress. Once the thoughts are determined, they are in a fashion attracted towards the perceptive end of the apparatus, as the issue of the hallucination suggests.

\section{THE INFANTILE SCENE}

For Freud, dream and hallucination are not very distant. They both configure thoughts as a scene and in that way they provide an experience. Many times in The Interpretation..., excessively vivid dreams are denominated hallucinatory dreams. The most renowned example is the dream of a child in flames that opens the seventh chapter of the book, many times referred to by Lacan (1964) in his Seminar 11. The Four Fundamental Concepts of Psychoanalysis. Freud argues that thoughts turned into scenes, because of hallucination, have a narrow connection with the underlined memory, with an 'infantile memory' (FREUD, 1900/2012, p. 574). He doesn't disregard the possibility of the same process occurring in dreams:

(Then), we cannot deny the probability that in dreams, too, the transformation of thoughts into visual images may be the result of the attraction exercised by the visually represented memory, striving for resuscitation, upon the thoughts severed from the consciousness and struggling for expression. Pursuing this conception, we may further describe the dream as the substitute for the infantile scene modified by transference to recent material. The infantile scene cannot enforce its own revival, and must therefore be satisfied to return as a dream. (FREUD, 1900/2012, p. 574)

There's a subtracted scene that commands the whole oneiric figuration. It allows - by the attraction its intact vividness has - the dream-work to reach the perceptive pole of the psychic apparatus. Without using the term 'trauma' explicitly, Freud firmly articulates this concept with the condensation and perceptive vividness in the dream. As Rivera (2012) notes, Freud anticipates himself, by suggesting that the dream repeats the trauma, as he will explicitly state in 1920 when he conceives the death drive and a functioning of the drives not subject to the pleasure principle. 
In Beyond the Pleasure Principle (1920), Freud expands his initial model of the psychic apparatus with a layer whose only function is protection. This layer would be the border of the apparatus and, as a consequence of the constant impact of exterior stimuli, it would suffer a calcification of sorts, moving from a role as a wrap, as a membrane resistant to the stimuli from the outside world. In this text, excitations coming from the outside are conceived as traumatic and so strong that they break the shield that protects theapparatus. When the protective barrier is breached in that violent way, an unexpected excess of stimuli floods the psychic apparatus. Once that the invasion is inevitable, the only thing lest is the attempt to dominate the incoming excitation retroactively. That attempted domination happens through the effort of linking the excessive excitation that broke through and that starts circulating freely in the apparatus, creating chaos where it goes.

It is only through the dream that Freud can speculate about the functioning of drives, which doesn't seem to be subject to the pleasure principle. The patients' nightmares - reproducing night after night the scene of the trauma - are what allow him to understand that such dreams do not fulfill wishes. In their obedience of the repetition compulsion, such dreams are involved in a task that needs to be performed before the pleasure principle can enter the scene. Each repetition is an attempt to retrospectively dominate the excessive excitation that violently entered the psychic apparatus, breaking the protective shield and disrupting the whole established functioning of the drives.

And that evidently repetitive functioning of nightmares allows us to see, in a broadened scale, the inherent functioning of any dream, whose original function wouldn't be fulfilling whishes but to conspire against traumatic excess by means of repetition. Surprisingly, that's what we already find in the 1900 text, in the idea that the dream is a replacement of the traumatic infantile scene. A scene that cannot be remembered (and even less so forgotten), which is 'incapable of imposing its renovation', and therefore needs to settle with its return disguised in the shape of a dream.

In that direction, in his interpretation of the The Interpretation..., Rivera (2012) understands that the dream is, before becoming an incarnation of wishes, a staging of the trauma. That's the reason why it would have a fundamental role in psychic elaboration, since we would every night dream the same crucial infantile scene, reshaped and restructured through lines of wishes. For the author, the staging of the trauma in a nightmare seeks - through the deadly submission to an external event - to fixate a position of wishing subject.

As Freud suggests, that infantile scene 'remains vividly visual' (1900/2012, p. 574) and it attracts dream-thoughts to the same form of visual figuration it has. It is in the direction of trauma that dream-thoughts regress. As we have just 
noted, the most condensed ones are capable of regressing inverting the perceptive system, even the whole perceptive vividness. That conception of a dream shows a narrow link between trauma and condensation. In that link, the two elements seem to work together for the constitution of the dream and therefore in the psychic elaboration of the subject.

\section{TRAUMA AND THE PRINCIPLE OF DREAM REPRESENTATION}

It is with regards to that power of attraction of the infantile scene that Freud assumes a connection of the scene with what he called 'regard for representability' — the conditions that the dream imposes to transform dream-thoughts into visual elements. The dream seems to choose thoughts that will have their representational content converted into sensorial images. Only thoughts that have some kind of connection to the infantile scene will regress to visual form. Everything indicates that the most concentrated thoughts are stronger and can go a longer distance inside the apparatus in direction to the perceptive end. Possibly the most condensed thoughts come to touch the infantile scene and emerge then as excessively vivid elements of the dream.

We have then a narrow link between trauma and the principle of dream representation. As Pontalis (1990) underlines, the dream representability is the only inherent restriction of the dream that we don't find in other formations in the subconscious. Jokes, parapraxis, symptoms and forgetfulness strengthen the condensation and displacement principles, but do not involve representation. It is exclusively in dreams that language is transformed into a perceptive image.

Despite Pontalis' affirmation that the dream is subject to 'the imperious need to make representable' (1990, p.42), it is worth remembering that not every dream is made of images. Dreams without images might be rare, but they exist. An example is Freud's own dream, the one in which he simply woke up with one meaningless word in his mind: 'Autodidasker' (FREUD, 1900/2012, p. 321). The condensation is here evident, and he then deconstructs it in author + autodidact + Lasker (a name). For this type of dream, Freud doesn't think of regression. In it, the thought seems to follow the progressive direction of the apparatus. A mere reduction of the censorship between pre-consciousness and unconsciousness would enable thoughts to move from one area to the other. That reduction of censorship is insufficient to explain hallucinatory dreams, which imply regression.

The principle of dream representation establishes that the trauma determines, ultimately, the representation. Everything that is turned into a scene in the dream has some connection to the infantile scene. If in the dream there is an image, it's because there's trauma. Or even: it is the trauma what makes us dream. 


\section{THE WRITING PAD AND THE TRACE}

As we mentioned earlier, the mnemonic systems would be between the perceptive end and the motor end of the psychic apparatus. For Freud, the perception that reaches the apparatus can be preserved as a trace. That would be the role of such systems - to preserve memory-traces. And these traces would be the foundations of memory.

From the early constructions on the psychic functioning, Freud assumes there is a division between reception and storage. Even in the 'Project for a Scientific Psychology' (FREUD, 1950 [1885]/1996) there is a separation between perceptive and mnemonic neurons. While ones would store traces of passage, others would remain unaltered by the passage of energy, always ready for new receptions. In The Interpretation... such separation is reprised in the conception of the psychic apparatus that has a system (the most external one) deprived from memory. The perceptive layer barely receives the external stimuli, and it doesn't preserve anything from them. The subsequent systems would be the ones responsible for the storage of the memory-traces, hence susceptible to constant alterations as new stimuli leave new traces and can also alter previous ones.

After conceiving an optical apparatus that can store memory-traces, Freud comes across the magic block. A toy whose construction presents 'a remarkable concordance' with the hypothetical structure he proposed for the perceptive apparatus. In A Note upon the Mystic Writing Pad (FREUD, 1924-25/1996), Freud understands writing as an externalization of the psychic apparatus and establishes comparisons that lead us to understand the psychic apparatus as a system of writing in layers.

The Notepad, as his apparatus model, has three layers. The first one, made of celluloid, protects the thin paper sheet that lies under it, and finally we find a wax slab. In this notepad, any writing or drawing made can magically be deleted. With a gesture that interrupts the contact between the layers that conform to it, the surface is clean again as if it had never been used.

The toy's celluloid layer works as a protective shield, in the same way as the calcified and more external layer of the apparatus. Both layers barely soften the external stimulus and do not store any traces. In the next layer of the notepad, the paper one, it is possible to write traces. These are temporarily present in the toy, just until the contact between the paper sheet and the wax slab is interrupted and the surface is once again virgin and ready for new impressions. That layer is the one that Freud compares to the Pcpt-Cs system, which has no memory. Stimuli go through it, but it is in the unconscious that traces remain. The same thing happens in the notepad: when the upper layers are held under adequate light, it is possible to see that the traces are inscribed, as carved in the depth of the wax slab. 
But, as Freud correctly underlines, there is a point in which our apparatus is even more magical than the notepad (FREUD, 1924-25/1996, p. 258). The toy is not capable of reproducing from within a writing that has been deleted in the surface. That reproduction 'from within' is a truly magical fact our apparatus is not only capable of, but, as it seems, it does it all the time. What would a dream be if not a reproduction of that deleted and at the same time forever undeletable trace?

We can call them trauces: traces that are traumas and that supply the implicit 'magic' needed by the memory apparatus, since it, with the excess drive that remains in it, gives life to language.

\section{THE PERCEPTIVE POINT OF LANGUAGE}

Freud doesn't question himself again with regards to dream regression in the text about the mystical notepad. In case he did, combining it with the 1900 scheme, maybe it would have taken him to differentiate two types of trace reproduction: the one made by memory and the one of revival. Inscriptions are combined forming representations that can become conscious, making a progressive journey through the layers of the psychic apparatus. But they can also emerge in a directly perceptive way, keeping their original vividness, in a regressive trajectory in the apparatus. In this last mode, they can go to the extreme of jeopardizing any possibility of representation, by means of the direct appearance -in all its intensity, in excess - of a given inscription.

In the progressive trajectory, representations are formed in which language takes the lead making an inscription, a type of writing able to compose narratives. In the regressive trajectory, the trace is presented as such, keeping its original intensity. That would be the trajectory that makes the dream possible, insofar as something (the 'infantile scene') is inscribed in the psychic apparatus in a perceptive way, and distanced from the representative work, maintaining an intensity able to attract representations moved in it towards its mode of representation. Regression can be conceived, hence, as a way in which the trauma functions, the way in which Freud conceived it since 1912 as a repetition (FREUD, 1914/1996, p. 165).

What we call here'revival' seems to be confirmed by the interesting Freudian remark that, in the dream, phrases said by someone else correspond to phrases actually heard in real life (FREUD, 1900/2012, p. 431). But all the dream-work shows that it's not only that in the formation of dreams: it is rather a complex network of representation operation in which language - especially in the condensation mode- plays the main role, as we have mentioned. What differences dreams from other psychic products is, however, the perceptive vividness that 
such treatment of inscriptions obtains in the end, thanks to regression. That is the point that makes the dream the via regia for the unconscious (FREUD, 1910 [1909]/1996, p. 32): it shows the functioning of the trauma. Only hallucinations (and delirium, in a second place) could eventually deserve, for the same reason, a similar status.

The excessive intensity of some elements in a dream (as in a screen memory) testifies this especial connection to trauma. This must not be taken, however, as a trace among the rest but as a trace that inaugurates and registers the infantile scene in the psychic apparatus as a hard core, a navel, a gutter through which representations risk vanishing, motionless, facing the intensity of something that holds the ego to the point of almost annihilating it. Right in that limit point of the representation, language shows it substitution structure and the catenation via condensation and displacement.

As the dream of the Irma's injection with its trimethylamine formula, besides revealing its combinatory structure (especially condensing) by touching the limit point of the representative work, language also shows an extreme density which is some kind of perceptive materiality. That point remembers and verifies that the psychic apparatus is not merely a notepad, notes from traces, but an optical apparatus, or even better: an apparatus that reproduces perceptions. It operates in the point in which language touches the body, where letter, number, representation (always remade) of the subject itself were already located. The original scene.

More than a narratively constructed scene, as the Freudian notion of Fantasy is usually interpreted; it is somewhat like Borges' aleph. Seeing all the places of the world in a single point, from every possible angle. An experience so excessive, disruptive, transforming (and why not say traumatic, beyond wonderful), Borges decides to name it with one letter. A sacred letter: soundless at the same time as it contains the whole principle of human articulation, it imbues meaning while it is meaningless. Maybe that's also how the trauma is, that original trauma that makes us dream, maybe it's just a letter inscribed in the apparatus.

It is the source of all narrative but also of the limitation of all interpretation. A letter barely heard, but that allows all speech. It is a living image that is barely an image, but will notwithstanding give rise to the construction of all images; a point outside the subject — God's speech, in the cabbalistic mythology — that is appointed in its dependency from language. Nothing but the first letter of anokhi, as we have seen: the word I, said by the Other. 


\section{BIBLIOGRAPHICAL REFERENCES}

BLANCHOT, M. (2005) O livro por vir. São Paulo: Martins Fontes.

BORGES, J. (1949/2008) O Aleph. Tradução de Davi Arriguci Jr. São Paulo: Companhia das Letras.

FREUD, S. (1984/1989) "Sobre a coca”. In BYCK, R. (org.). Freud e a cocaína. Rio de Janeiro: Espaço e Tempo.

FREUD, S. (1900/2012) A interpretação dos sonhos, v. I e II. Tradução de Renato Zwick e revisão técnica de Tania Rivera. Porto Alegre: LP\&M

FREUD, S. (1996) Edição Standart brasileira das obras psicológicas completas de Sigmund Freud. Rio de Janeiro: Imago.

(1950 [1885]) “Projeto para uma psicologia científica”, v. I, p. 335- 470. (1899) “Lembranças encobridoras”, v.III, p.285 - 306.

(1910 [1909]) “Cinco lições de psicanálise”, v. XI, p. 17 - 66.

(1914) “Recordar, repetir, elaborar”, v. XII, p. 159 -174.

(1920) "Além do princípio de prazer”, v. XVIII, p.13 - 78.

(1924-25) "Uma nota sobre o bloco mágico", v. XIX, p. $253-262$.

LACAN, J. (1954-55/1985) O seminário, livro 2: O eu na teoria de Freud e na técnica da psicanálise. Rio de Janeiro: Jorge Zahar.

LACAN, J. (1964/2008) O seminário, livro 11: os quatro conceitos fundamentais da psicanálise. Rio de Janeiro: Jorge Zahar.

PONTALIS, J.-B. (1991) A força de atração. Rio de Janeiro: Jorge Zahar.

RIVERA, T. (2002) Arte e psicanálise. Rio de Janeiro: Jorge Zahar.

. (2008) Cinema, imagem e psicanálise. Rio de Janeiro: Jorge Zahar. (2010) "A letra e o espaço literário. Jorge Luis Borges e o Real na literatura." In SCOTTI, S.; Bergamaschi, R.; Lange, M. et alli. Escrita e Psicanálise II. Curitiba: CRV.

. (2012) "O sonho e o século". In: FREUD, S. A Interpretação dos

Sonhos. Porto Alegre: LP\&M.

SCHOLEM. G. (2006) A cabala e seu simbolismo. São Paulo: Perspectiva.

SOSNOWSKI, S. (1991) Borges e a cabala. São Paulo: Perspectiva.

Tainá Pinto

tainahop@gmail.com

Tania Rivera

taniarivera@uol.com.br

Traduzido do português por Alejo Magariños/translated from portuguese by Alejo Magariños. 